\title{
Growth and chronology of the rhodolith-forming, coralline red alga Sporolithon durum
}

\author{
Nicolas Darrenougue ${ }^{1, *}$, Patrick De Deckker ${ }^{1}$, Claude Payri $^{2}$, Stephen Eggins ${ }^{1}$, \\ Stewart Fallon ${ }^{1}$
}

\author{
${ }^{1}$ Research School of Earth Sciences, The Australian National University, Canberra 0200, Australia \\ ${ }^{2}$ Institut de Recherche pour le Développement, UR227, Nouméa, New Calédonia
}

\begin{abstract}
We report extension rates and growth patterns of the coralline red alga Sporolithon durum (rhodolith form) from New Caledonia. Alizarin red S staining was used to mark 43 rhodolith branches and helped determine extension rates over the rhodoliths' last living year. A combination of radiocarbon dating, major $\mathrm{Mg} / \mathrm{Ca}$ ratio cycles and growth band determinations provided a chronological approach to characterise extension rates for 5 branches over the last 5 decades. A seasonal asymmetry in the extension rates was observed, with higher extension during the austral summer-fall-winter period, indicating that variations in ambient seawater temperature are not of major influence in the seasonal growth pattern of $S$. durum. At the sub-seasonal level, minor growth bands were observed with a maximum frequency of $14 \mathrm{~d}$ but were too variable to be considered as a reliable chronological tool. The concordance of the results from both the monitoring experiment over the year 2010 to 2011 and the chronological approach applied to the period 1968 to 2008 suggests that an extension rate (mean $\pm \mathrm{SD}$ ) of $0.6 \pm 0.2 \mathrm{~mm} \mathrm{yr}^{-1}$ is typical of the $S$. durum community at the study site. However, annual extension rates varied considerably among branches and individuals. Long-term trends still appeared, such as a decrease during the early 1970 s attributed to the impact of mining activity. A slight but consistent decrease was observed in the annual extension rates throughout the record and may reflect an ontogenic effect potentially enhanced by reduced light penetration due to increasing suspended particulate matter in the water column.
\end{abstract}

KEY WORDS: Crustose coralline algae - Extension rate - Radiocarbon - Seasonal pattern · New Caledonia

\section{INTRODUCTION}

Rhodoliths are unattached nodules essentially composed of calcareous coralline red algae. As they grow, deposits of calcium carbonate form a calcareous skeletal structure that can be preserved after the death of the algae and may accumulate, along with the skeletons of other organisms of the same community, over thousands of years (Freiwald et al. 1991, Basso 2012). Fossil coralline red algae occur in the geological record since the Cretaceous (Aguirre et al. 2000). The modern distribution of these organisms spans all latitudes, from the tropics to the poles, and ranges from the intertidal zone down to the limit of the photic zone (Foster 2001). The major contribution of coralline red algae to reef building, in tropical as well as extra-tropical regions, has been recognised in numerous studies (e.g. Borowitzka 1983, Littler \& Littler 1988, Foster 2001, Schäfer et al. 2011, Basso 2012). In the tropics, coralline red algae are often associated with coral reefs where their calcareous skeletons provide the cement that is crucial for consolidating the reef structure (e.g. Steneck 1997, Payri 1997, Payri et al. 2001).

Early studies focused mainly on the ecology and the taxonomy of coralline red algae (see Adey \& 
MacIntyre 1973 and Bosence 1983b for reviews). In recent years, interest has arisen in using these organisms as environmental archives because of their global distribution and their slow growth rates (between 0.01 and $2.7 \mathrm{~mm} \mathrm{yr}^{-1}$; Böhm et al. 1978, Foster 2001) associated with the thick crusts they form (up to several $\mathrm{cm}$ ). The geochemical composition of the coralline algal skeleton has been shown to record various environmental parameters (in particular, Mg:Ca ratio - thereafter referred to as $\mathrm{Mg} / \mathrm{Ca}-$ variations can record changes in seawater temperature at sub-annual resolution over decades to centuries; Halfar et al. 2000, Kamenos et al. 2008, Hetzinger et al. 2009, 2011, Kamenos 2010; but see also Frantz et al. 2000, Halfar et al. 2007, Chan et al. 2011, Williams et al. 2011). Calcification changes have also been used for environmental reconstruction (Burdett et al. 2011, Halfar et al. 2011a,b), as various species of coralline red algae display calcification rates varying with environmental conditions, in particular light and seawater temperature (e.g. Foster 2001, Kamenos \& Law 2010).

In seasonally contrasted regions, annual cycles in calcification can be observed as couplets of light and dark bands characterised by short, heavily calcified cells usually produced during the winter months and longer, less calcified cells produced in summer (e.g. Basso 1994, 1995, Halfar et al. 2008, Kamenos \& Law 2010), a property useful in establishing chronologies for palaeo-environmental reconstructions (e.g. Burdett et al. 2011). This occurs along with changes in $\mathrm{Mg}$ content of the coralline red algal calcite skeleton, covarying with seawater temperature, which result in well-defined $\mathrm{Mg} / \mathrm{Ca}$ annual cycles (Hetzinger et al. 2009, 2011, Chan et al. 2011). In addition to the major, annual banding, several coralline red algae species display higher-frequency minor bands. The recurrence of these sub-annual bands remains uncertain, although they have generally been interpreted either as marking growth cessation (Cabioch 1966) or as representing approximate monthly or lunar cycles (Agegian 1981, Freiwald \& Henrich 1994, Blake \& Maggs 2003). The growth rate and pattern of coralline red algae vary, both from species to species (Blake \& Maggs 2003) and with various environmental conditions (Adey \& MacIntyre 1973, Foster 2001). Therefore, it is crucial to evaluate these parameters for any particular species prior to attempting palaeo-environmental reconstructions. Furthermore, a better understanding of the growth rate and pattern of coralline red algae is a key to assess how these organisms will be affected by global climate changes in the future.
Sporolithon durum (Foslie) Townsend \& Woelkerling is a widely distributed coralline red algal species belonging to the recently recognised order Sporolithales (Le Gall et al. 2010, Bittner et al. 2011). $S$. durum occurs either as attached or as free-living forms, from the tropics to temperate oceanic environments (e.g. Townsend et al. 1995, Womersley 1996, Goldberg \& Heine 2008, Basso et al. 2009). Previous reports on modern, individual rhodoliths with a potential lifespan of several decades (e.g. Goldberg $\&$ Heine 2008) indicate this species may be a suitable candidate for environmental reconstructions with sub-annual resolution. However, accurate growth rates and pattern information on $S$. durum have not previously been determined.

Accordingly, we aimed to characterise the extension rates and growth patterns of Sporolithon durum, through in situ monitoring of rhodoliths in a tropical environment and by establishing multi-approach chronologies for nodules collected from the same rhodolith bed. This is the first time this type of study has been conducted for the coralline red algal order Sporolithales.

\section{MATERIALS AND METHODS}

\section{Study site and sample collection}

The rhodoliths studied here were collected near Nouméa, New Caledonia, by SCUBA diving on the outer edge of the Ricaudy Reef $\left(22^{\circ} 18^{\prime} 57^{\prime \prime} \mathrm{S}\right.$, $\left.166^{\circ} 27^{\prime} 26^{\prime \prime} \mathrm{E}\right)$ in the SW lagoon of New Caledonia, at depths ranging from 4 to $5 \mathrm{~m}$ (Fig. 1). The climate of New Caledonia is characterised by a tropical regime with pronounced seasonal variation from a hot and wet summer (January to March) to a cool and humid winter (July to August), with drier weather occurring during the intermediate months (April to May and September to December). On an inter-annual timescale, the climate system is mainly influenced by the El Niño Southern Oscillation (ENSO) phenomenon, with typically cool and dry periods during El Niño events and warm and wet periods during La Niña events (Nicet \& Delcroix 2000). Seawater temperatures closely follow the atmospheric temperatures at seasonal and inter-annual scales.

The studied rhodoliths are monospecific and formed by the coralline red alga Sporolithon durum that was identified using histological analyses as the most abundant species at the site, and which forms beds that can entirely cover the substratum. The sampled rhodoliths were spheroidal in shape with thick and 


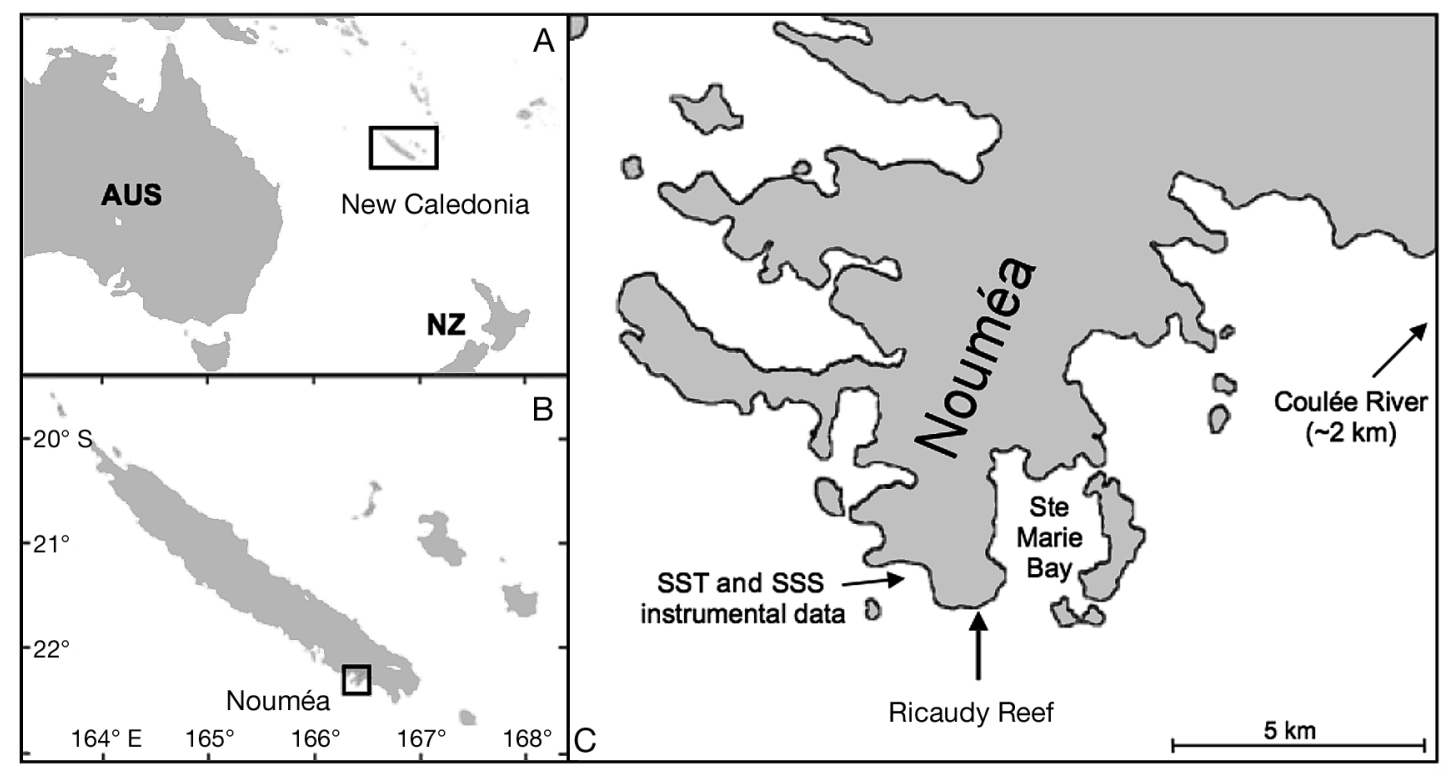

Fig. 1. (A) New Caledonia in the tropical Western Pacific. (B) Nouméa, the capital city. (C) The Ricaudy Reef, at the south end of the Sainte Marie Bay, near Nouméa. The site of sea surface temperature (SST) and salinity (SSS) measurements and the direction and distance to the Coulée River mouth is shown

dense branches ('degree IV' branching structure according to the classification of Bosence 1983a). The nodules ranged in size from $\sim 4$ to $>8 \mathrm{~cm}$ (long axis), and were representative of the $S$. durum rhodoliths observed at the site.

In February 2011, >60 rhodoliths were collected for the growth-monitoring experiment. For the chronology and extension rate determination of entire nodules, 3 rhodoliths were selected from separate dives in October 2009 (labelled specimen BSA) and February 2011 (specimens MSA and SSA) as being the largest and visually healthiest (i.e. bright pink in colour and physically undamaged) specimens encountered during the dives.

\section{Monitoring experiment}

Staining, experimental conditions and sample preparation

The specimens collected for the monitoring experiment were placed for $48 \mathrm{~h}$ in tanks, each containing $\sim 10 \mathrm{l}$ of seawater from the Ricaudy Reef, in which $75 \mathrm{mg}$ of Alizarin Red S (ARS) powder was dissolved (method adapted from Payri 1997). After staining, the rhodoliths were placed back into their natural environment, inside a $\sim 1 \times 1 \mathrm{~m}$ enclosure built within the rhodolith bed (4 to $5 \mathrm{~m}$ deep), for the duration of the experiment (Fig. 2A). A TinyTag TG-4100 Aquatic 2 temperature logger was attached to the enclosure to monitor hourly in situ temperature (IST) in the immediate vicinity of the organisms. IST recording using this device started in November 2009. All of the stained rhodoliths were retrieved in August 2011, after $196 \mathrm{~d}(28 \mathrm{wk})$ in the enclosure. Seven specimens representative of the size range of the $>60$ stained rhodoliths were selected, oven dried $\left(40^{\circ} \mathrm{C}\right)$ and set into resin to preserve the fragile branching structure during the sectioning process. Thick sections (2 to $5 \mathrm{~mm}$ ) were cut along the long axis of the nodules using a diamond rock-saw. High-resolution photographs of the polished sections were obtained using a Digital Sight DS-Fi1 digital camera attached to a Nikon AZ100 optical microscope (Fig. 2B,C).

\section{Growth determination}

Based on the definitive presence of the ARS stain layer (see Fig. 2C), 43 branch tips from the 7 selected rhodoliths were analysed for their extension rate and growth pattern (see Table S1 in the supplement at www.int-res.com/articles/suppl/m474p105_supp.pdf). High-resolution digital images were processed using the ImageJ version 1.45 digital analysis software (http://rsbweb.nih.gov/ij) to measure growth with a precision of $1 \mu \mathrm{m}$. Measurements were systematically taken along the axis of branch main growth, perpendicular to cell alignment, so the maximum extension 

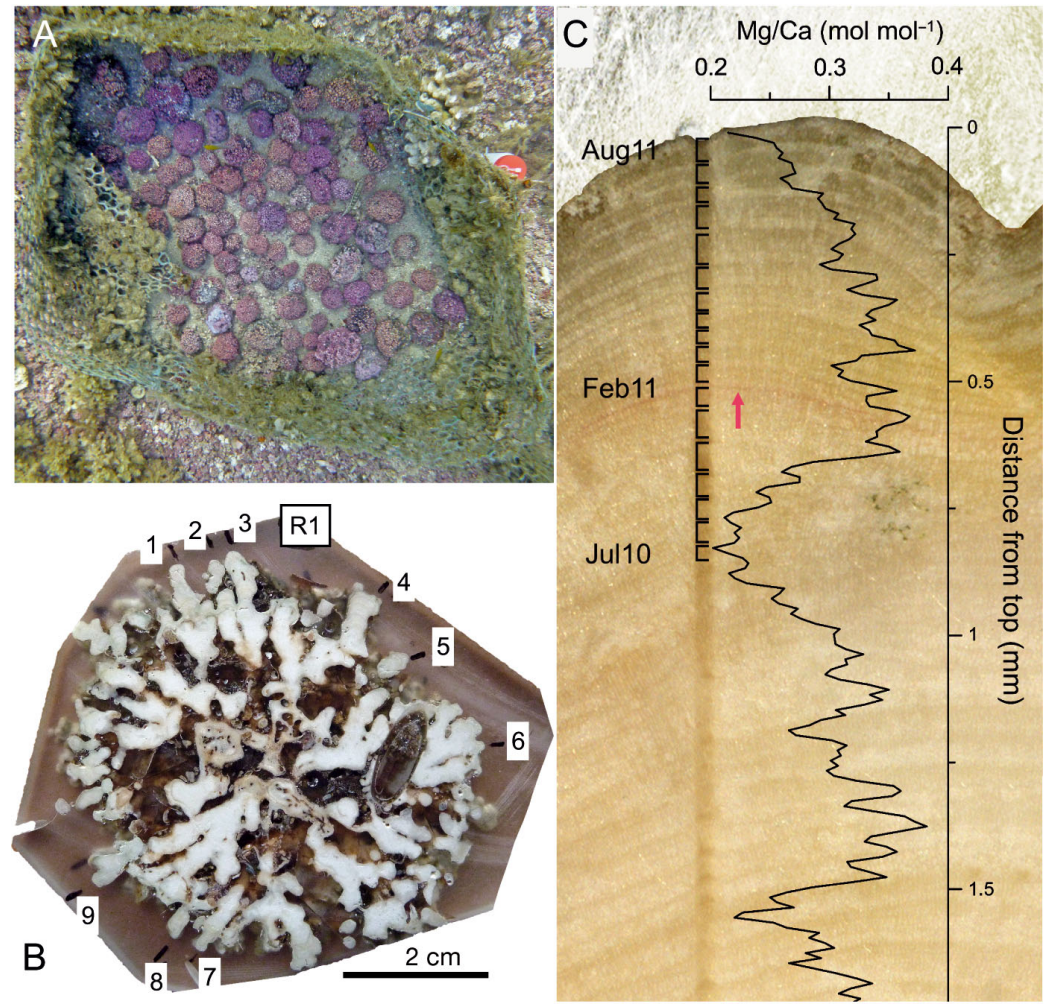

Fig. 2. Monitoring experiment and growth rate determination for Sporolithon durum. (A) Rhodolith enclosure $(\sim 1 \times 1 \mathrm{~m})$ at Ricaudy Reef. Photograph taken $2 \mathrm{~d}$ after staining (February 2011). (B) Epoxy block sectioned across the long axis of a monitored rhodolith (mostly white in colour), showing the branch-tips analysed (black ticks with numbers). (C) Close up of the R1-4 branch tip, showing the Mg/Ca variations recorded by LA-ICPMS. The pink Alizarin red S stain layer (arrow) corresponds to February 2011. The top of the branch is August 2011 and the following lowest Mg/Ca peak was attributed to July 2010. Minor bands are indicated by square brackets
The minor banding was determined visually from digitised high-resolution images by the alternation of clear and darker layers of cells (Fig. 2C). The number of minor bands from the stained layer to the surface of the branch was reported for the period February to August 2011 (hereafter 'Feb-Aug11'), and the number from the penultimate lowest value of the $\mathrm{Mg} / \mathrm{Ca}$ cycle to the stained layer was attributed to the period July 2010 to February 2011 (hereafter 'Jul10Feb11'). The average length of the minor bands was calculated from the distance measured for each period and the corresponding observed number of minor bands.

\section{Back-scattered electron images}

To characterise the growth pattern of Sporolithon durum at the cellular level, we used a Cameca SX100 electron microprobe at the Research School of Earth Sciences (RSES) of the Australian National University (ANU) to obtain back-scattered electron (BSE) images. The BSE images were captured from a $1 \mu \mathrm{m}$ polished, carbon coated thin section of a rhodolith branch. rate could be obtained. The distance from the pink Alizarin-stained layer to the surface layer of each branch tip was attributed to the growth during the 28 wk monitored period (February to August 2011).

Annual growth rates were determined using the outermost $\mathrm{Mg} / \mathrm{Ca}$ cycle recorded along each branch that was measured by laser ablation inductively coupled plasma mass spectrometry (LA-ICPMS - see e.g. Eggins et al. 1998) with a $30 \mu \mathrm{m}$ resolution corresponding to a sub-monthly sampling. Based on the observed covariance between $\mathrm{Mg} / \mathrm{Ca}$ variations and seawater temperature in coralline algae (e.g. Halfar et al. 2000, Kamenos et al. 2008, Hetzinger et al. 2009), we were able to link the lowest $\mathrm{Mg} / \mathrm{Ca}$ values to the months with the lowest temperature of the last 13 mo (July 2010 and August 2011). The distance corresponding to this 13 mo period for each branch was then linearly transformed to obtain 12 mo, i.e. annual growth rates.

\section{Chronology and extension rate of entire nodules}

The sample preparation for the BSA, MSA and SSA rhodoliths followed the same method described above for the analysis of the monitored specimens. As no obvious mark of cessation of growth (i.e. green algal levels or sign of breakage) was observed in any of the rhodolith thick sections, we considered the organisms to have grown continuously throughout their living period.

\section{Radiocarbon dating}

Samples (10 mg) of rhodolith carbonate skeleton were obtained by drilling along 2 branches situated on the long (BSA_L; Fig. 3A) and short (BSA_S) axes of the BSA nodule. Every hole (1 to $2 \mathrm{~mm}$ in diameter) 
was drilled with a 2 to $3 \mathrm{~mm}$ step from top to bottom along the branches. Radiocarbon measurements were carried out at the ANU, using the single stage accelerator mass spectrometer facility (Fallon et al. 2010). The $\mathrm{CO}_{2}$ was liberated from the carbonate samples by addition of phosphoric acid to vacuumsealed blood vials; the $\mathrm{CO}_{2}$ was then reduced to graphite using an Fe-catalyst in the presence of hydrogen (Vogel et al. 1987). IAEA C-1 marble $\left({ }^{14} \mathrm{C}\right.$ free) was used for background subtraction. Results are presented in percent Modern Carbon (pMC). The data analysis software AnalySeries (Paillard et al. 1996) was used to fit the pMC values to the calibrated pMC curve obtained by Fallon et al. (2003) for a coralline sponge from Vanuatu, following the atomic bomb curve from the 1950s. Similarities in the

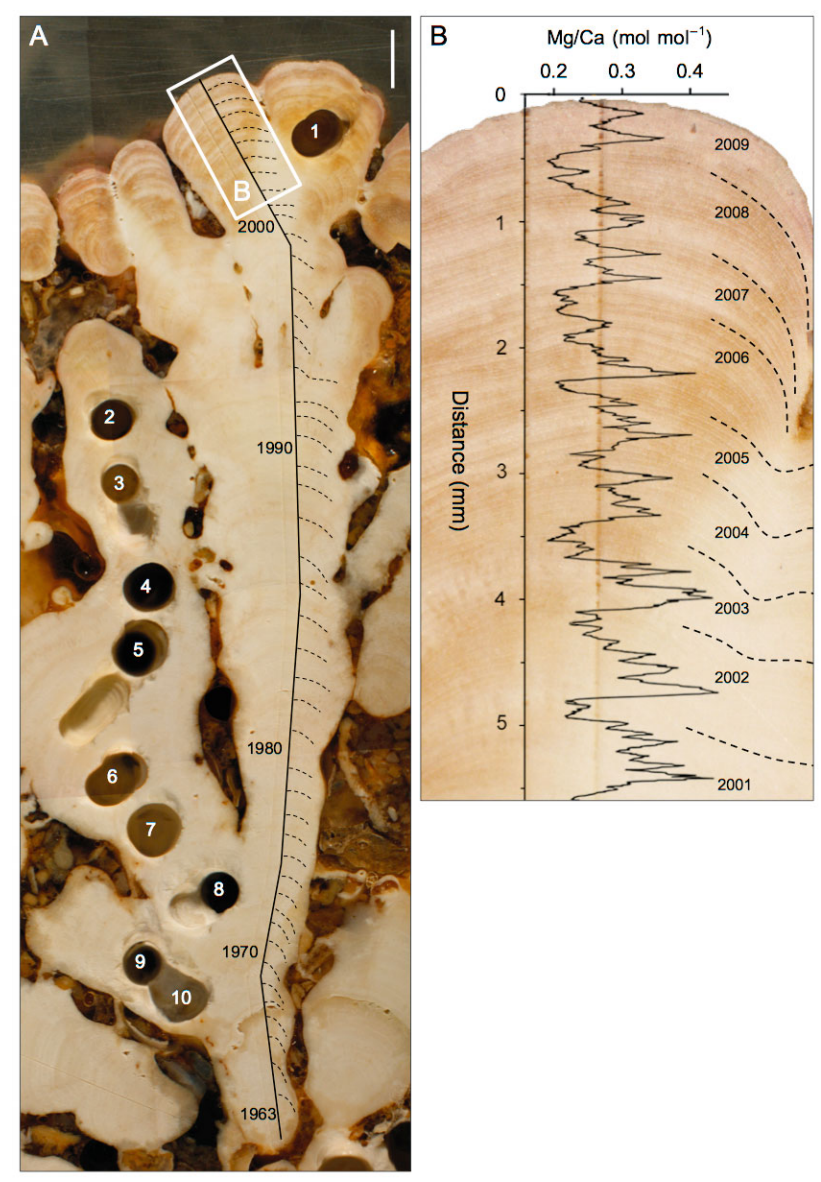

Fig. 3. Age model for the BSA1 branch. (A) BSA1 branch showing the location of the BSA_L radiocarbon samples (numbered holes: 1 to 10 ), the LA-ICPMS track (black line) and the estimated annual increments (dotted lines) determined by the combination of $\mathrm{Mg} / \mathrm{Ca}$ cycles and major growth band counting. (B) Close up of the specimen in (A) showing the determination of annual increments using both $\mathrm{Mg} / \mathrm{Ca}$ cycles and major growth bands, as well as the corresponding years oceanography of the Vanuatu and New Caledonia regions, both located at the northwestern edge of the South Pacific gyre, likely produced similar trends in the variations of the oceanic ${ }^{14} \mathrm{C}$ enrichment in the area after the atomic bomb tests, thus making the calibration of Fallon et al. (2003) suitable to our study. This fitting method, which does not require any reservoir effect correction, is commonly used to establish age models for modern (i.e. post 1950) samples, when the sampling resolution is sufficient (e.g. see Frantz et al. 2000 for a rhodolith).

Due to the relatively large amount of carbonate material needed to perform the radiocarbon analysis, in conjunction with the generally slow growth rate of coralline red algae, the sampling technique is likely to be responsible for an uncertainty close to 1 to $2 \mathrm{yr}$ on every date. The analytical errors on the pMC values averaged $0.3 \%$. This, in combination with the small pMC variations recorded after the bomb spike for the Vanuatu sponge (Fallon et al. 2003), leads to an additional date uncertainty of a couple of years based on the curve-fitting process. Overall, we estimated the age uncertainty of each radiocarbon date to be $>1$ yr but to not exceed 5 yr.

\section{Band counting and $\mathrm{Mg} / \mathrm{Ca}$ cycles}

The radiocarbon chronology for the BSA rhodolith was compared to an independent chronological approach mainly based on the determination of the seasonal Mg/Ca cycles along each branch (Fig. 3), as previously used for various species of coralline red algae (e.g. Hetzinger et al. 2009, 2011, Gamboa et al. 2010). With the aid of the AnalySeries software (Paillard et al. 1996), we used the low points in $\mathrm{Mg} / \mathrm{Ca}$ cycles as anchor points that were matched to the coolest months of successive years in the sea surface temperature (SST) record. The distance between 2 anchor points determines reported annual extension rates.

Using a $30 \mu \mathrm{m}$ diameter spot for the LA-ICPMS analysis of rhodoliths, we achieved a sub-monthly resolution. However, despite efforts to cut a sampling surface exactly parallel to the main axis of growth, the 3-dimensional complexity of the branches' structure at high resolution may lead to bands that appear compressed or stretched. This, in addition to other potential factors influencing seasonal and subseasonal $\mathrm{Mg} / \mathrm{Ca}$ distribution and variability in the analysed Sporolithon durum rhodoliths (full details will be reported in a separate communication; Darrenougue et al. unpubl.), sometimes prevented us from 
distinguishing clear minima in the $\mathrm{Mg} / \mathrm{Ca}$ variations. In such cases, the identification of major, annual bands on the high-resolution photographs confirmed the boundaries of the seasonal cycles. It must be noted that the major, annual banding was not always clear (e.g. Fig. 3B); however, using both the major banding and the major $\mathrm{Mg} / \mathrm{Ca}$ cycles enabled us to compensate for the uncertainty of either method. As a result, we estimated the age uncertainty of this model to be $<1$ yr.

\section{Environmental dataset}

Météo France and the Institut de Recherche pour le Développement (IRD) provided monthly records of local SST, global solar radiation, rainfall and wind strength for the period 1960 to 2011. The Direction des Mines et de l'Energie de Nouvelle Calédonie provided the annual mining production data the for duration of the mining activity in the Coulée region.

\section{RESULTS}

\section{Monitored rhodoliths}

Measured growth from the Alizarin stain to the surface of each of the 43 branch tips ranged from 0.146 and $0.894 \mathrm{~mm}$ with a mean $\pm \mathrm{SD}$ of $0.452 \pm 0.176 \mathrm{~mm}$ (Table S1). This corresponds to a growth range of 33 and $80 \%$, respectively, of the total Jul10-Feb11 growth period, with an average of $65 \pm 12 \%$. With the exception of a few branches (mainly belonging to the R2 rhodolith), the greatest rhodolith growth in the last 13 mo occurred during Feb-Aug11 (Fig. 4). Both the linear and logarithmic fits between measurements of the latter 2 periods displayed highly significant correlation coefficients $\left(\mathrm{r}^{2}=0.72\right.$ and $\mathrm{r}^{2}=$ 0.82 , respectively; $\mathrm{p}<0.0001$ ), indicating covariance between the proportion of growth occurring in FebAug11 and annual extension rates.

The asymmetrical seasonal growth pattern recorded for Sporolithon durum and the patterns of the studied environmental parameters do not correspond, as the latter globally displayed no significant differences (within error) between Jul10-Feb11 and Feb-Aug11 (Fig. 5).

The number of minor, sub-annual bands for the Feb-Aug11 period ranged from 3 (R2-2, R2-4, R4-1 and R5-2) to 14 (R1-2 and R1-5), half of which fell within 6 and 12 (Table S1). The length (mean \pm SD) of the minor bands occurring between February and

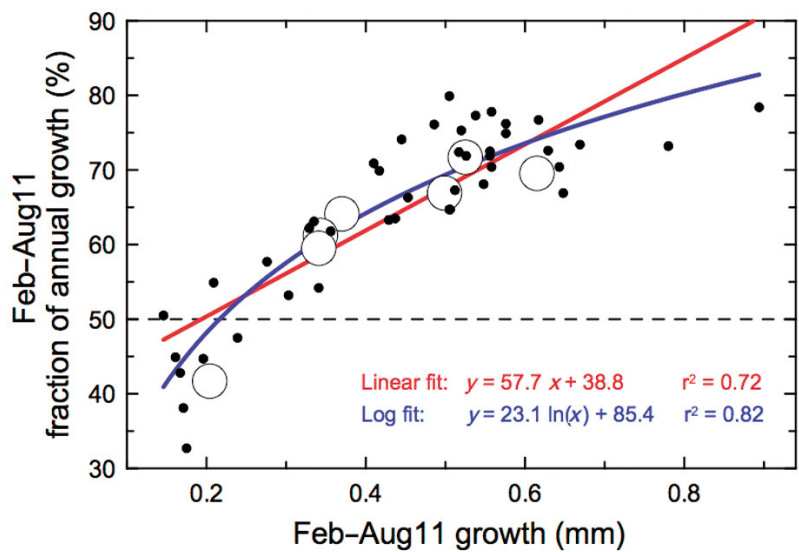

Fig. 4. Relationship between the rhodolith growth measured for the February to August 2011 (Feb-Aug11) growth period and the fraction of that growth over the July 2010 to August 2011 (Jul10-Aug11) period. •: individual measurements, O: means for each rhodolith. Linear (red) and logarithmic (blue) fits and equations are also displayed along with the respective correlation coefficients

August 2011 was $0.049 \pm 0.009 \mathrm{~mm}$, and individual values ranged between 0.030 and $0.070 \mathrm{~mm}$, for the R5-1 and R1-7 branches, respectively. For the Jul10Feb11 period, fewer minor bands were generally observed than for Feb-Aug11. Typically, 3 to 9 bands occurred in each branch. These minor bands also appeared to be slightly shorter, with a length of $0.039 \pm$ $0.007 \mathrm{~mm}$ and a range of $0.023(\mathrm{R} 7-5)$ to $0.054 \mathrm{~mm}$ (R1-1; Table S1).

The close-up optical image, as well as its corresponding scanning electron microscopy image, showed that the minor, sub-annual bands were composed of alternating cells with different lengths and degrees of calcification. One or more cell rows can form a sub-annual band (Fig. 6).

The measured extension rates for the year 2010 to 2011 are reported in Table S1, with the distribution and summary statistics presented in Fig. $7(\mathrm{n}=43)$. Extension rates ranged from 0.267 to $1.053 \mathrm{~mm} \mathrm{yr}^{-1}$ and averaged $0.622 \pm 0.170 \mathrm{~mm} \mathrm{yr}^{-1}$, with $50 \%$ of the values occurring between 0.493 and $0.720 \mathrm{~mm} \mathrm{yr}^{-1}$.

\section{Entire rhodolith specimens}

\section{Radiocarbon dating}

Radiocarbon results for the BSA_L and BSA_S branches are presented in Fig. 8 and Table 1. pMC values (mean $\pm \mathrm{SD}$ ) for the BSA_L branch showed a steady decrease from $114.9 \pm 0.3$ in the sample nearest to the start of growth, to $109.1 \pm 0.4$ at the top 


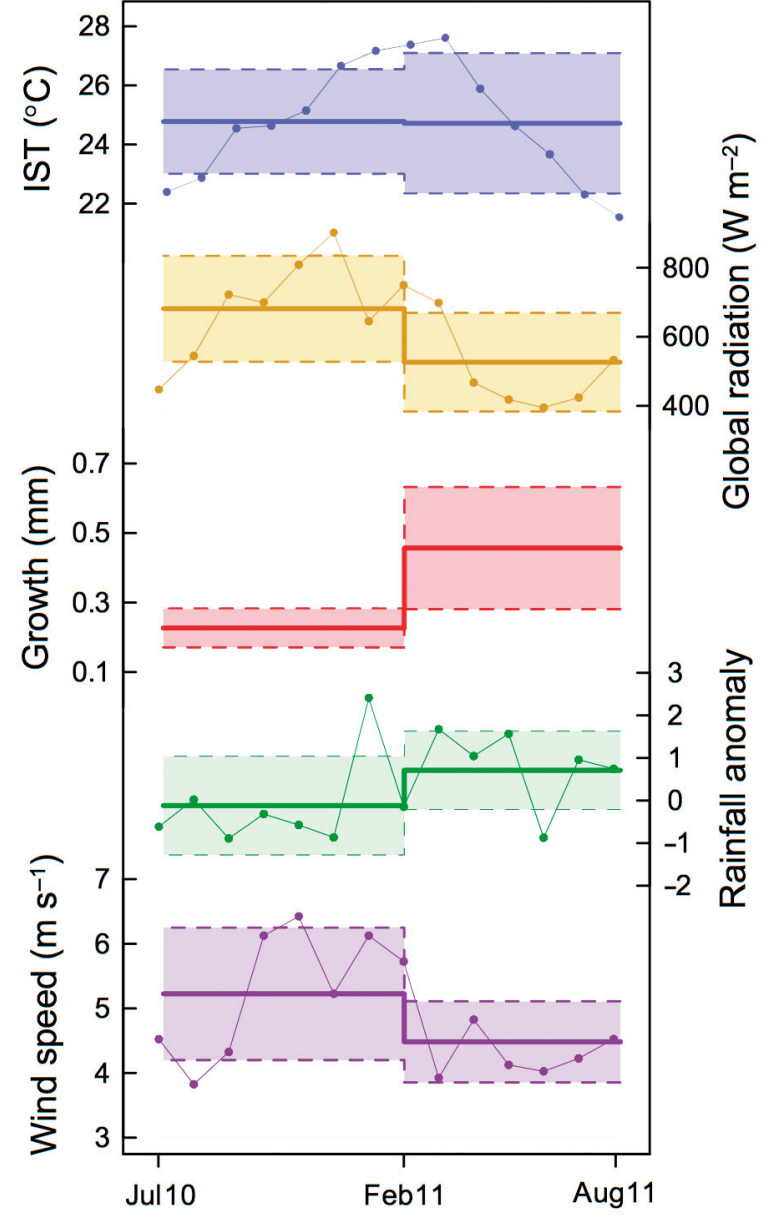

Fig. 5. Environmental parameters recorded either at the study site (in situ temperature: IST) or for the nearby Nouméa station (global radiation, rainfall anomaly and wind speed; data from Météo France) and rhodolith extension between July 2010 and August 2011. Bold lines: averages for the 2 periods Jul10-Feb11 and Feb11-Aug11. Thin lines and markers: monthly mean data. Shaded areas: \pm 1 SD (based on monthly mean data for environmental variables, and on measurements of 43 branches during the 2 periods)

of the branch. pMC values for the BSA_S branch increased sharply from $103.8 \pm 0.3$ to $113.9 \pm 0.3$ close to the centre of the rhodolith, then, as for BSA_L, steadily decreased to a value of $107.7 \pm 0.3$ near the top of the branch. The sharp increase and then slow decrease in the BSA_S branch pMC values matches the evolution of the atomic bomb spike in the South Pacific region, from the late 1950s to the early 1970s, also recorded in corals (e.g. Toggweiler et al. 1991, Guilderson et al. 2000) and sponges (Fallon et al. 2003). The BSA_L pMC values did not record this sharp increase, and therefore, the oldest radiocarbon date was considered to be younger than 1970 .

The radiocarbon chronology gave an oldest date of 1972 for the BSA_L branch (long axis) and of

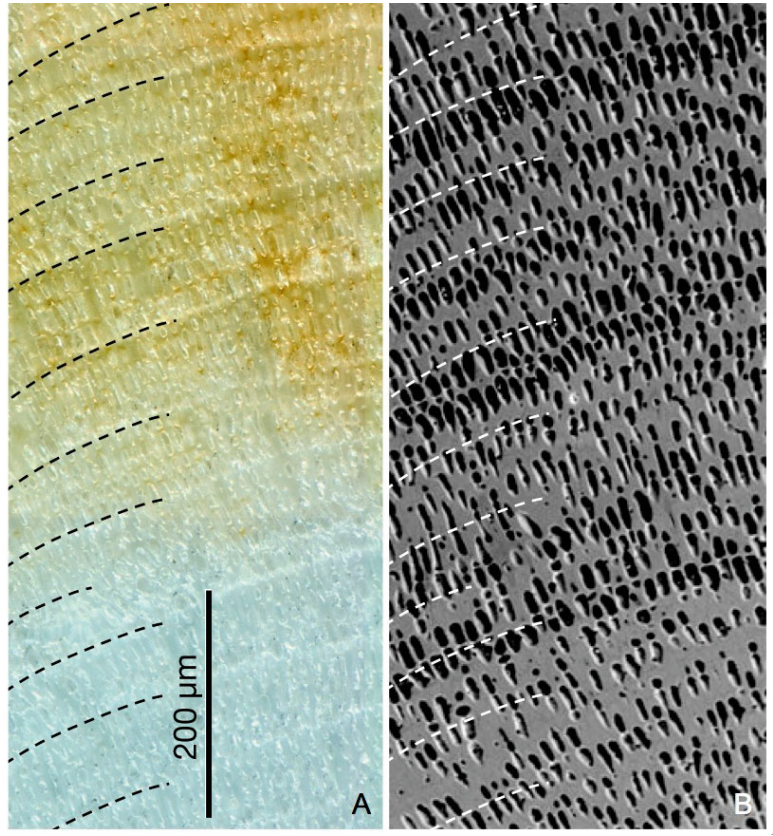

Fig. 6. (A) Optical image and (B) corresponding back scattered electron (BSE) image of a portion of a rhodolith branch where the minor banding is clearly visible (dashed lines) and consists of the alternation of small, heavily calcified cell layers and longer, less calcified ones. Also note the general trend from small, heavily calcified cells at the bottom of the BSE image towards longer, less calcified cells at the top of the image, which constitutes the major banding pattern. The growth direction of the specimen is from the bottom to the top of the images

$\sim 1963$ for the BSA_S branch (short axis) of the same specimen (Fig. 8). This age difference can be explained by the difference in sampling locations, as, unlike for the BSA_S branch, the BSA_L branch was not sampled down to the absolute centre of the rhodolith. Regardless, considering the different branch lengths, these 2 series of dates imply distinct extension rates. The average annual extension rate along the long axis (BSA_L) was $0.8 \mathrm{~mm} \mathrm{yr}^{-1}$, whereas along the short axis, it was $0.5 \mathrm{~mm} \mathrm{yr}^{-1}$.

Mg/Ca cycles and major growth bands

The radiocarbon chronology established for the BSA specimen was supported by the Mg/Ca cycles and major-band counting approach. The oldest record for the BSA rhodolith was 1963 for the BSA1 branch (corresponding to the BSA_L branch). The 2 other branches of the BSA specimen dated to 1965 for BSA2, corresponding to the BSA_S branch, and 1964 for BSA3. The agreement between these dates indicates an age of $\sim 46$ yr for the BSA rhodolith. $\mathrm{Mg} / \mathrm{Ca}$ 


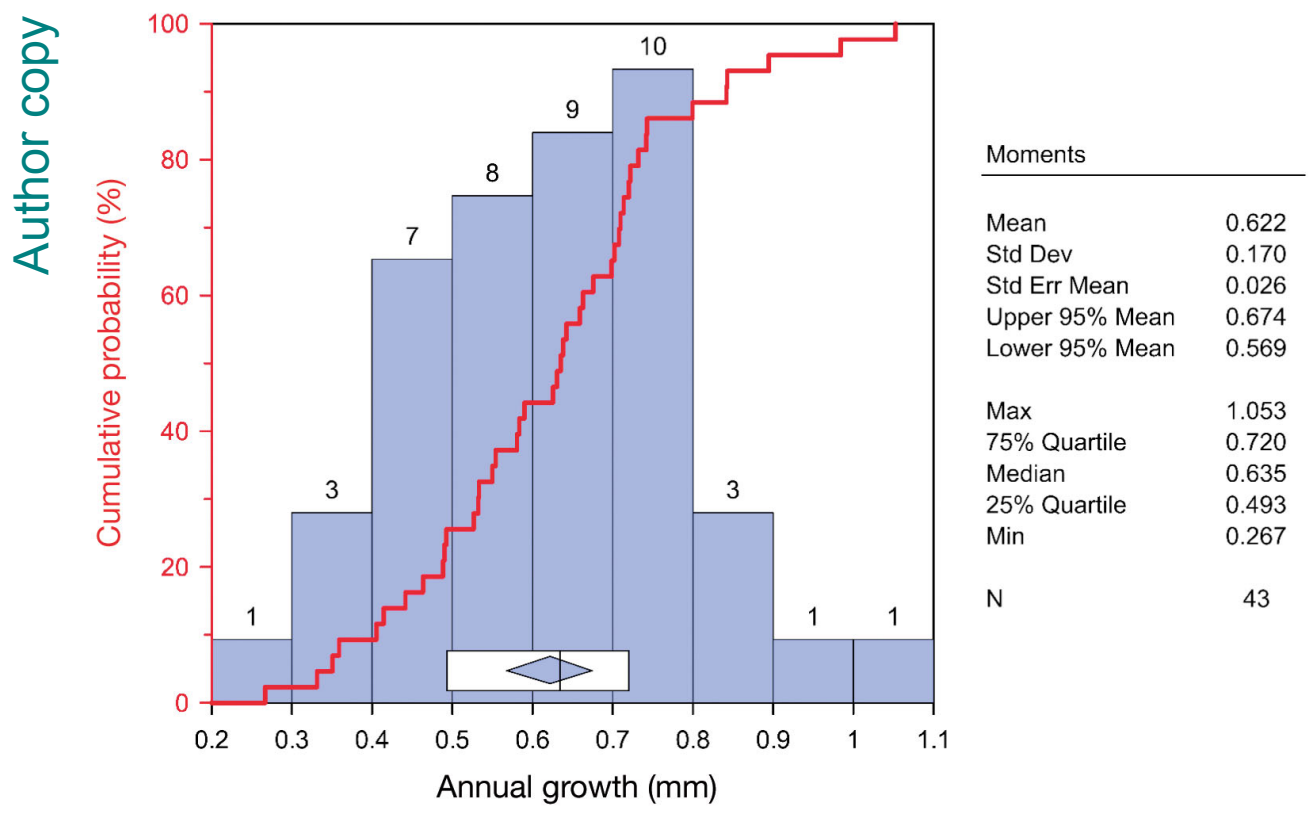

Fig. 7. Distribution plot and cumulative probability plot of annual growth recorded for the monitored rhodoliths. The blue histogram shows the number of branch tips with annual extension sorted in bins of $0.1 \mathrm{~mm}$, from $0.2-0.3$ to $1.0-1.1 \mathrm{~mm}$. The step plot (red line) displays the cumulative distribution function of the extension rates versus the cumulative probability measured from the 43 tips. The white box at the bottom of the bar chart illustrates the statistical moments of the series (table at right): the edges of the box are the 25 and $75 \%$ quartiles, the line inside the box is the median value and the blue diamond represents the mean (vertical diagonal; not shown) and the lower and upper $95 \%$ mean values (left and right corners)

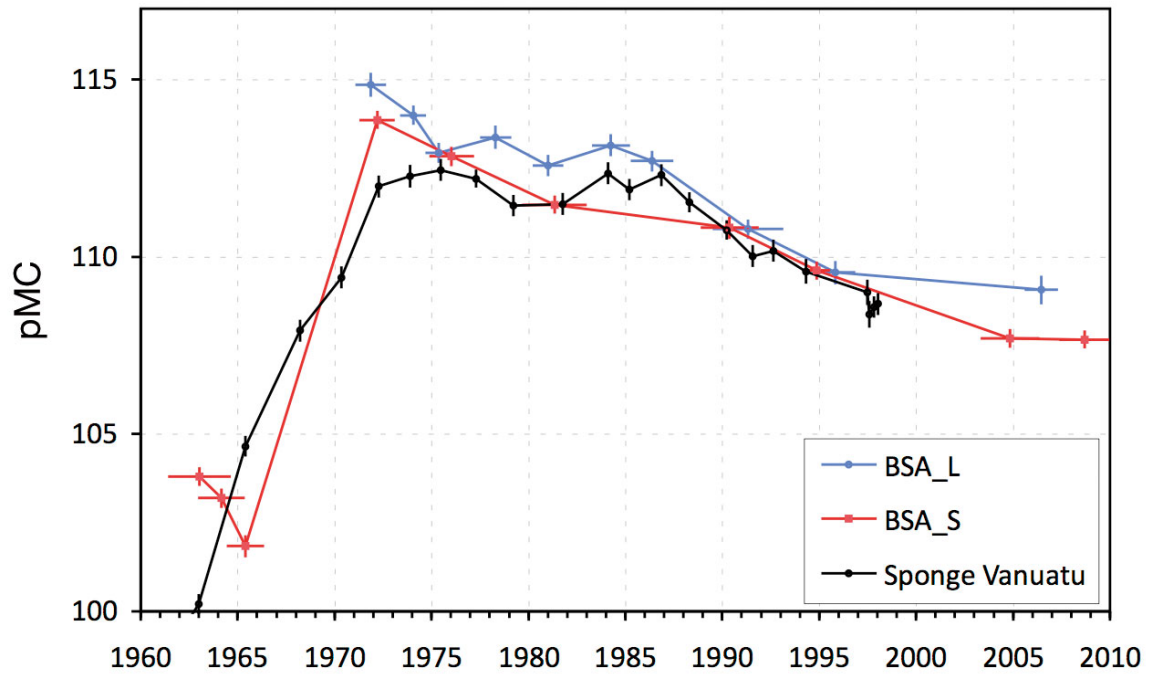

Fig. 8. Radiocarbon age model for 2 branches (BSA_L and BSA_S) of the BSA rhodolith based on a previously age-calibrated coralline sponge from Vanuatu (Fallon et al. 2003). The horizontal error bars on the rhodolith's radiocarbon data correspond to the size of the sampled material (1 to $2 \mathrm{~mm}$ along the branch, corresponding to 1 to $4 \mathrm{yr}$ intervals - see 'Materials and methods'). pMC: percent modern carbon

cycles and major-band counting gave an age of $48 \mathrm{yr}$ for the MSA1 branch and 49 yr for the SSA1 branch, with an oldest date of 1962 .

The annual extension rates for the BSA, MSA and SSA rhodoliths, measured along 5 branches for the period 1963 to 2010, ranged from 0.19 to $1.24 \mathrm{~mm} \mathrm{yr}^{-1}$ with a mean $\pm \mathrm{SD}$ of $0.64 \pm 0.23 \mathrm{~mm} \mathrm{yr}^{-1}(\mathrm{n}=227$; Table S2 in the supplement). For each branch, annual

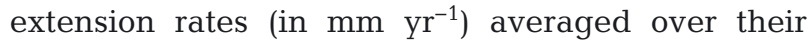
respective living period were $0.78 \pm 0.25$ (BSA1), $0.50 \pm 0.19(\mathrm{BSA} 2), 0.66 \pm 0.25(\mathrm{BSA} 3), 0.66 \pm 0.20$ $(\mathrm{MSA})$ and $0.61 \pm 0.19(\mathrm{SSA} 1 ;$ Table 2$)$.

Annual extension rates varied widely among the 5 measured branches (Fig. 9, Table 3), with only the BSA1-SSA1 pair showing a significant, albeit weak, correlation at the $95 \%$ confidence interval $(r=0.34$; $\mathrm{p}=0.02)$. Despite this, a slightly decreasing trend appeared in the average extension rates over the last 5 decades, and the early 1970 s also displayed shorter annual extension rates for most of the branches (Fig. 9).

No significant correlation at the $95 \%$ confidence interval ( $\mathrm{p}>0.05$ for all correlations) was observed between the annual data of Sporolithon durum annual extension rates and any of the environmental parameters recorded in Nouméa for the period 1964 to 2008 (Fig. 10). However, shorter extension rates in the early 1970s are contemporaneous with the peak of mining activity in the Coulée region. 


\section{DISCUSSION}

\section{Seasonal growth pattern in Sporolithon durum}

The monitoring experiment revealed a general asymmetric seasonal growth pattern in $S$. durum, with higher overall growth measured during the

Table 1. Radiocarbon results for rhodolith branch BSA_L (long axis) and BSA_S (short axis). Distance values are presented as center \pm radius of the sampling hole and pMC values are mean $\pm \mathrm{SD}$. Calibrated dates were determined using the AnalySeries computer program (Paillard et al. 1996). Typical uncertainty on calibrated dates is $<5$ yr (see 'Materials and methods' for details)

\begin{tabular}{|lrcc|}
\hline $\begin{array}{l}\text { Sample } \\
\text { no. }\end{array}$ & $\begin{array}{c}\text { Distance from } \\
\text { top }(\mathrm{mm})\end{array}$ & $\begin{array}{c}\text { Percent modern } \\
\text { carbon }(\mathrm{pMC})\end{array}$ & $\begin{array}{c}\text { Calibrated } \\
\text { date }\end{array}$ \\
\hline BSA_L & & & \\
1 & $2.9 \pm 0.7$ & $109.1 \pm 0.4$ & 2007 \\
2 & $11.7 \pm 0.9$ & $109.6 \pm 0.3$ & 1996 \\
3 & $14.7 \pm 1.5$ & $110.8 \pm 0.3$ & 1991 \\
4 & $19.6 \pm 0.9$ & $112.7 \pm 0.3$ & 1986 \\
5 & $21.2 \pm 0.8$ & $113.2 \pm 0.3$ & 1984 \\
6 & $23.2 \pm 0.7$ & $112.6 \pm 0.3$ & 1981 \\
7 & $25.5 \pm 0.6$ & $113.4 \pm 0.3$ & 1978 \\
8 & $28.0 \pm 0.6$ & $112.9 \pm 0.3$ & 1975 \\
9 & $28.9 \pm 0.6$ & $114.0 \pm 0.3$ & 1974 \\
10 & $30.7 \pm 0.6$ & $114.9 \pm 0.3$ & 1972 \\
BSA_S & & & \\
1 & $2.4 \pm 0.8$ & $107.7 \pm 0.3$ & 2009 \\
2 & $4.6 \pm 0.9$ & $107.7 \pm 0.3$ & 2005 \\
3 & $7.1 \pm 0.4$ & $109.6 \pm 0.3$ & 1995 \\
4 & $9.9 \pm 0.9$ & $110.8 \pm 0.3$ & 1990 \\
5 & $13.7 \pm 1.0$ & $111.5 \pm 0.3$ & 1981 \\
6 & $16.0 \pm 0.7$ & $112.8 \pm 0.3$ & 1976 \\
7 & $18.3 \pm 0.6$ & $113.9 \pm 0.3$ & 1972 \\
8 & $21.0 \pm 0.6$ & $101.8 \pm 0.3$ & 1965 \\
9 & $23.1 \pm 0.7$ & $103.2 \pm 0.3$ & 1964 \\
10 & $25.6 \pm 1.0$ & $103.8 \pm 0.3$ & 1963 \\
& & & \\
\hline
\end{tabular}

Feb-Aug11 period, associated with greater minorband widths. Consequently, for Jul10-Feb11, slower overall growth was observed as well as narrower minor bands. This is consistent with previous studies reporting that during faster (slower) growth periods, the cells formed by coralline red algae are generally longer (shorter), albeit presenting less (more) heavily calcified walls. It is this seasonal contrast in the cell length and calcification that forms the recognisable major, annual banding in various species of coralline

Table 2. Annual extension rates (mean \pm SD) measured for 5 different rhodolith branches over the period 1963 to 2011 using the combination of major growth banding and $\mathrm{Mg} / \mathrm{Ca}$ cycles. n: number of years for each branch. See Table S2 in the supplement for full dataset

\begin{tabular}{|lcc|}
\hline Branch & $\mathrm{n}$ & $\begin{array}{c}\text { Annual extension } \\
\text { rate }\left(\mathrm{mm} \mathrm{yr}^{-1}\right)\end{array}$ \\
\hline BSA1 & 45 & $0.75 \pm 0.29$ \\
BSA2 & 43 & $0.49 \pm 0.19$ \\
BSA3 & 44 & $0.66 \pm 0.25$ \\
MSA1 & 47 & $0.66 \pm 0.20$ \\
SSA1 & 48 & $0.62 \pm 0.21$ \\
\hline
\end{tabular}

Table 3. Correlation matrix for extension rate variations for the period 1964 to 2008, between each rhodolith branch analysed. None of the correlations are significant at the $95 \%$ level ( $p>0.05)$, except for ${ }^{*} p=0.02$

\begin{tabular}{|llrlr|}
\hline$r$ & BSA1 & BSA2 & BSA3 & MSA1 \\
\hline BSA2 & 0.23 & & & \\
BSA3 & 0.21 & 0.24 & & \\
MSA1 & 0.02 & -0.20 & 0.14 & \\
SSA1 & $0.34^{*}$ & 0.25 & 0.00 & -0.12 \\
\hline
\end{tabular}

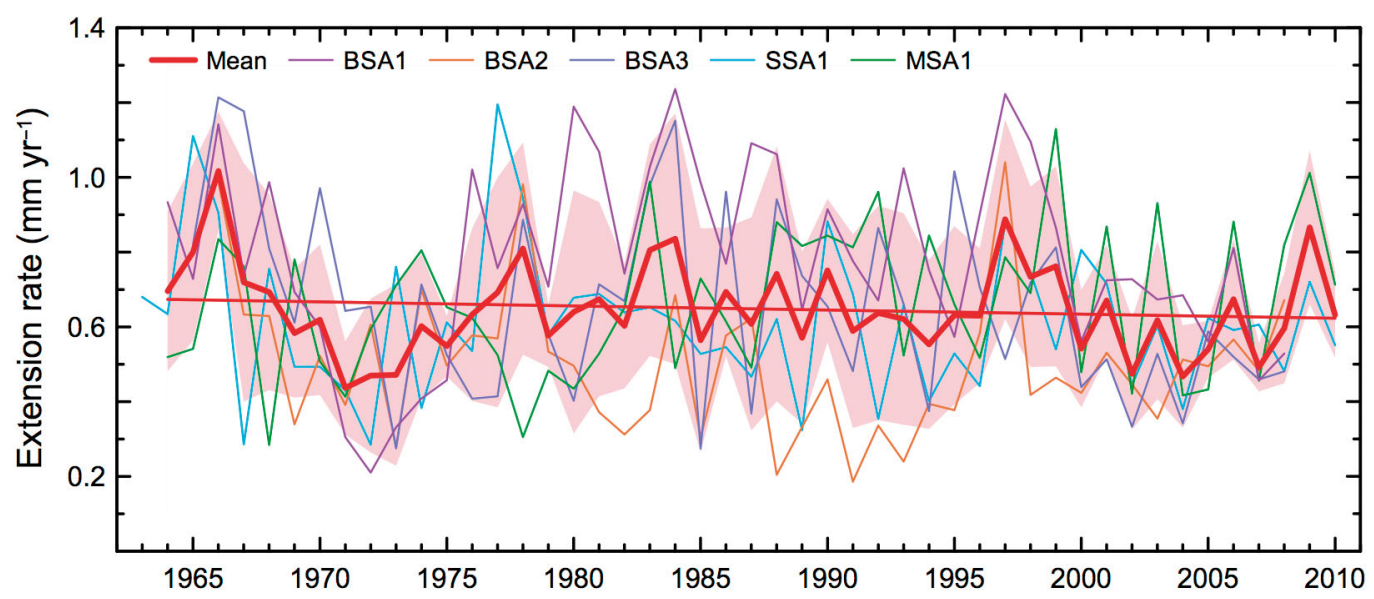

Fig. 9. Annual extension rates along 5 rhodolith branches (thin lines) for the period 1963 to 2010. Mean extension rate curve for the period 1964 to 2008 (thick red line), \pm 1 SD (shaded area) and the slightly decreasing trend line for the record (thin red line) are also displayed. For branch codes, refer to 'Materials and methods' 


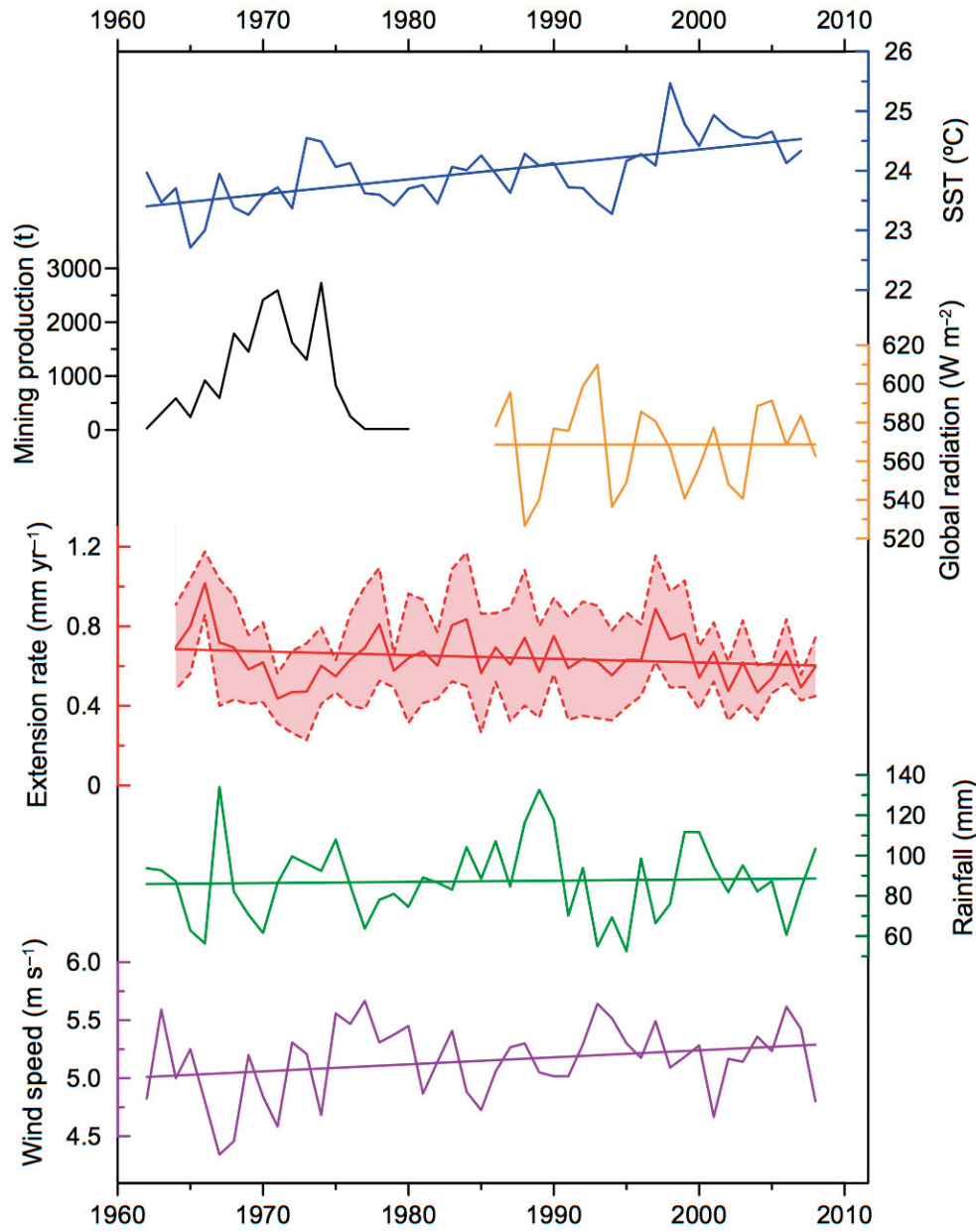

Fig. 10. Comparison between the annual variations of the average rhodolith extension rates recorded for the period 1964 to 2008 at the Ricaudy Reef and various local environmental parameters measured for the Nouméa meteorological station (data from Météo France). Trend lines of each parameter for the studied period are displayed. Global solar radiation data is only available since 1986 at the site. Annual mining production in the Coulée River region during the period 1960 to 1981 is also shown. SST: sea surface temperature be attributed to tidal cycles. Tidal cycles have never been observed in coralline red algal growth, but as they are intrinsically related to lunar cycles (i.e. half a lunar cycle), this is not a surprising result. Furthermore, 14 d growth patterns clearly appear in other marine organisms such as bivalve molluscs (e.g. Pannella 1976, Schöne et al. 2003, Hallmann et al. 2011) and brachiopods (Hughes et al. 1988). However, the fact that this pattern appears clearly in only 2 of our samples merits cautious interpretation. In addition, for Jul10Feb11, the maximum number of minor bands was 9. This excludes $14 \mathrm{~d}$ cycles, yet the highest observed frequency was also sub-monthly. One explanation for the absence of a $14 \mathrm{~d}$ pattern may reside in missing growth information due to the sampling process associated with the complex structure of the rhodolith branches or a regular overturning of the rhodoliths (see discussion below). However, if the observations accurately reflect the rhodolith growth pattern, they may reveal a temporally undetermined shift in the banding periodicity, from monthly to every $14 \mathrm{~d}$. It is plausible that during times of slow growth, minor banding is only observable every lunar cycle, whereas when growth conditions are more favourable, a tidally-influenced pattern may prevail. To our knowledge, such a shift in the periodicity of growth increments has thus far never been reported for any marine organism; however, the inconsistency of our observations calls for a future monitoring study of Sporolithon durum at a sub-monthly frequency to more rigorously assess this hypothesis.

The growth pattern that produces the annual, major banding in Sporolithon durum is repeated at the sub-seasonal level to also form the minor banding (Fig. 6). One to a few layers of each type of cells (i.e. short, heavily calcified and long, less calcified) appears to be part of the minor banding. Hence, single rows of cells might be formed as frequently as sub-weekly. However, the variability of this pattern precludes the determination of consistent periodicity for the deposition of a single row of cells.

In summary, it appears that, unlike for bivalve molluscs (Pannella 1976, Schöne et al. 2003, Hallmann et al. 2011) or some brachiopods (Hughes et al. 1988), the sub-seasonal, minor banding observed in this corresponds to a $2 \mathrm{wk}$ frequency and could therefore 
study for Sporolithon durum is too variable to be considered a useful chronological tool.

\section{Sporolithon durum ages and annual extension rates}

Thus far, the only previous dating of $S$. durum specimens was reported by Goldberg \& Heine (2008) for rhodoliths from Rottnest Island (Western Australia). Although these authors could not determine extension rates, their radiocarbon results estimated a maximum age for 3 specimens, ranging from 73 to $83 \mathrm{~mm}$ in diameter, to be 56 yr old (post 1950, for a collection in 2006), which is consistent with our findings.

The consistent annual extension rate (mean $\pm \mathrm{SD}$ ) of $0.6 \pm 0.2 \mathrm{~mm} \mathrm{yr}^{-1}$ indicated by both the in situ monitoring and the chronological approaches $(n=270)$ suggests that the presence of the enclosure had no significant effect on rhodolith growth, and that the observed extension rate value is typical of the Sporolithon durum community at the Ricaudy Reef. This extension rate is of the same order as previously reported values for other coralline red algal species (Table 4), albeit slightly higher than the global average for rhodoliths $\left(\sim 0.4 \mathrm{~mm} \mathrm{yr}^{-1}\right)$ reported by Foster (2001). To summarise Table 4, various species of Lithothamnion show annual extension rates ranging from 0.2 to $0.6 \mathrm{~mm}$ $\mathrm{yr}^{-1}$ according to study location or chronological approach (Rivera 1999, Frantz et al. 2000, Halfar et al. 2000, Kamenos et al. 2008, Schäfer et al. 2011). In colder areas, regardless of the studied species, annual extension rates are generally lower (Chave \& Wheeler 1965, Halfar et al. 2000, 2007, 2008, 2011a,b, Kamenos et al. 2008). We mainly attribute this to the temperature difference between these regions and the tropical waters of New Caledonia. However, environmental factors cannot always explain the differences (or similarities) in the extension rates of various species of coralline red algae; rather, it appears that an internal, species-specific effect sometimes prevails. For instance, the same extension rates have been reported for Phy-

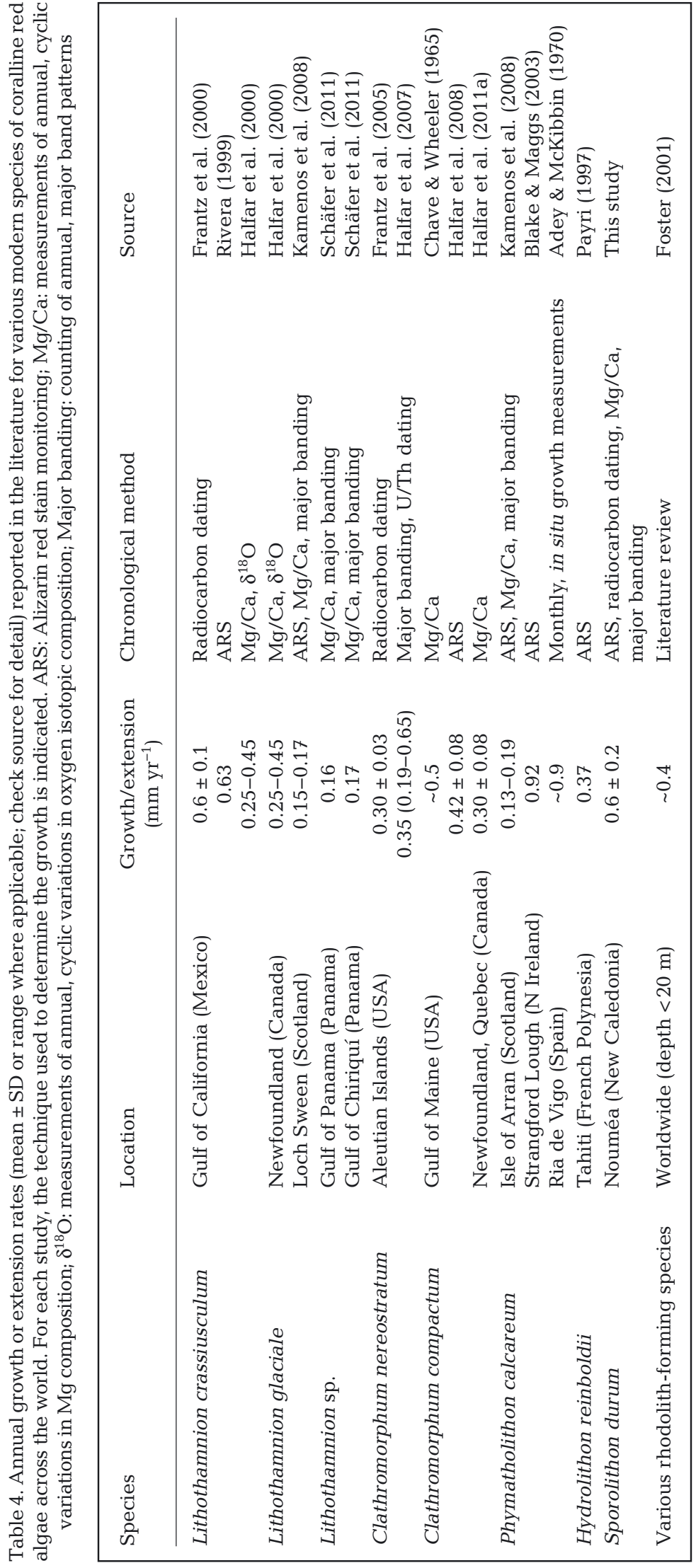


matholithon calcareum from a temperate (Spain; Adey \& McKibbin 1970) and a cold-water environment (Northern Ireland; Blake \& Maggs 2003). Conversely, Hydrolithon onkodes (Payri 1997) and S. durum (this study) present very different extension rates in a shallow tropical environment (Table 4).

\section{Controls on the Sporolithon durum extension rate variations}

Results from the monitoring experiment and from the chronological approach indicate extension rates for $S$. durum that can considerably vary for any given year, at different levels. The ellipsoidal shape of the $S$. durum rhodoliths may facilitate the overturning of the specimens about the long axis of growth. This would result in the parts at the opposite ends of the long axis of the nodule being more prone to remain under optimal living conditions throughout the growth period, whereas the remaining algal surface would periodically face the substratum. Although coralline red algae have been shown to have the ability to survive and continue to grow in a shaded environment for relatively long periods (e.g. Scoffin et al. 1985, Freiwald \& Henrich 1994, Bulleri 2006, Underwood 2006, Basso et al. 2009), Dethier \& Steneck (2001) showed that growth rates in the shade are generally lower than those recorded in direct light. In our case, lateral accretion of the nodules would be favoured most of the time, resulting in extension rates being greater parallel to the long axis of the rhodoliths relative to the short axis (see BSA_L/BSA1 versus BSA_S/BSA2). Therefore, irregular overturning of the nodules could play a significant role in explaining the variability in extension rates observed within the same rhodolith specimen. Episodic burial into the sediment might also slacken the rhodolith growth for variable periods of times, without necessarily stopping it (e.g. Freiwald \& Henrich 1994). This could account for some of the inter-rhodolith variability. Genetic variability resulting in individualised responses to the environment might also contribute to the inter-rhodolith variability.

The complex branch structure and 3-dimensional growth pattern of the rhodoliths may also provide a potential explanation for the reported extension rate variability along a single Sporolithon durum branch. It has been recognised that the sectioning process of a rhodolith branch could lead to the measurement of slightly shorter or longer extension rates than the actual linear extension rate of the organism along its axis of main growth (e.g. Halfar et al. 2000, 2011a,
Burdett et al. 2011, our study). Using attached forms of coralline red algae could reduce this type of variability (Halfar et al. 2000, 2011a). Unfortunately, no attached form of $S$. durum has been encountered at the Ricaudy site (N. Darrenougue and C. Payri pers. obs.).

Despite the significant variability in extension rates reported for Sporolithon durum in this study, overall, common trends in the growth pattern still stand out. At the seasonal level, it was unexpected that highest rhodolith growth consistently takes place between the months of February and August, which corresponds to the austral summer-fall-winter. Indeed, other studies of coralline red algae have generally presented higher growth rates during the springsummer period (e.g. Moberly 1968, Halfar et al. 2008). Spring and summer in New Caledonia are also the most favourable seasons for phytoplanktonic algal blooms (Rodier \& LeBorgne 2008) and benthic primary production (Clavier \& Garrigue 1999). Ambient seawater temperature does not explain the contrasted seasonal growth pattern of $S$. durum, as the IST at the monitoring site between the Jul10-Feb11 and the Feb-Aug11 periods remained virtually constant (Fig. 5). Seasonal contrast in global solar radiation at the site can also be ruled out in the explanation of the growth pattern observed here (Fig. 5). A potential factor on slower growth in spring is the record of higher wind velocity (Fig. 5) that may contribute to an increased resuspension of particles in the water column (e.g. Ouillon et al. 2010), leading to a reduced light penetration through the water column. Internal biological factors are also likely to play a large role in the control of the seasonal growth pattern of $S$. durum; however, their determination was beyond the scope of this study.

The absence of a correlation between the annual variations of the average extension rate recorded for the rhodoliths and the local environmental parameters for the period 1964 to 2008 (Fig. 10) was to be expected due to the high variability of extension rates displayed by the analysed branches. However, in the longer-term trends, it appears that the slight decrease in rhodolith extension rate during the early 1970s might be related to a period of intense mining production in the Coulée River region starting in the early 1960s and ending in 1981 (Fernandez et al. 2006). This period of highest mining production (up to 3000 tons of extracted material per year; Fig. 10) was also coeval, to some extent, with increased rainfall over Nouméa. Debenay \& Fernandez (2009) determined a drastic change in the depositional regime in western Sainte Marie Bay (Fig. 1) concordant with 
the intense mining activities in the Coulée River basin, likely caused by higher sedimentation rates. We suggest that an increased sediment load from the Coulée River into the lagoon might also explain the observed reduction of rhodolith growth during the mining activities due to higher turbidity of the lagoon waters leading to an effective reduction of the light penetration through the water column. However, $S$. durum show higher, more stable extension rates only a few years after the perturbation, when the sediment load transported by the Coulée River is likely to have remained high (Fernandez et al. 2006), suggesting the ability of $S$. durum to overcome periods of reduced irradiance (as previously suggested for other coralline red algal species, e.g. Wilson et al. 2004).

The slight decrease in average Sporolithon durum extension rates over the last 5 decades might result from stress caused by the slight temperature rise (Fig. 10); however, this is in contradiction with several studies showing that higher temperatures, as well as increased light intensity as observed here with the solar radiation (Fig. 10), have a positive effect, if any, on coralline red algal calcification and growth (Kamenos \& Law 2010, Dethier \& Steneck 2001). The observed decrease in extension rates may also reflect an ontogenic effect in S. durum. Coralline red algae are thought not to suffer from any ontogenic effect (e.g. Halfar et al. 2007, 2011a, Wanamaker et al. 2011, Williams et al. 2011); however, from our observations, such an effect that results in extension rates being slower as the organism ages cannot be ruled out for $S$. durum. In addition, the increasing trend of wind strength recorded over Nouméa might have contributed to stronger winddriven currents in the lagoon, thus favouring more sediment resuspension. The gradually increasing amount of particles in the water column may have reduced light availability for the rhodoliths, leading to a slight decrease in extension rates over the studied period. This is consistent with the propositions for the seasonal growth pattern observed in $S$. durum. This effect could also have been amplified by increased terrigenous inputs into the lagoon resulting from slightly increasing rainfall recorded over the studied period (Fig. 10).

\section{CONCLUSIONS}

We determined major (seasonal) and minor (subseasonal) growth patterns in Sporolithon durum rhodoliths from southwest New Caledonia through a staining experiment. The major, seasonal banding corresponds to the alternation of higher extension rates during the austral summer-fall-winter period, and lower extension rates during the winter-springsummer months. This seasonal contrast is associated with a respectively longer and shorter, sub-seasonal, minor banding. Minor bands, composed of 2 to several individual cell layers, were clearly observed and appeared to have a maximum periodicity of $14 \mathrm{~d}$. However, as this $14 \mathrm{~d}$ periodicity could not be characterised in the majority of the analysed branches, especially during periods of slower growth, we consider the minor bands in $S$. durum rhodoliths to be too variable to represent a reliable chronological tool.

Typical extension rates (mean $\pm \mathrm{SD}$ ) for the Sporolithon durum community were $0.6 \pm 0.2 \mathrm{~mm} \mathrm{yr}^{-1}$, which is in good agreement with reports for other coralline red algal species in the literature. Extension rates of $S$. durum rhodoliths present a considerable variability for any given year. However, common, longer-term trends in the inter-annual variations could be distinguished and related to environmental factors. Intense mining activities that occurred in the Coulée River basin until 1981 and peaked in the early 1970s appear to have had an adverse effect on rhodolith growth that lasted several years before recovery to higher, more stable extension rates. Although the slight decrease in rhodolith extension rate observed over the last 5 decades potentially reflects an ontogenic effect, it may also have been enhanced by a gradual reduction of light penetration in the lagoon waters caused by an increase in current-driven sediment resuspension and/or terrigenous inputs. No influence of the seawater temperature on the pattern or rate of extension in the $S$. durum rhodoliths was observed at any of the studied scales.

Acknowledgements. We are very grateful to J. Butscher (IRD) for invaluable help with the rhodolith collection and throughout the monitoring experiment. The late G. Cabioch (IRD) was instrumental in organising this research project. We thank R. Rapp (RSES) for the SEM analyses and T. Phimphisane, J. Vickers and R. Norman (RSES) for technical help. Funding for this research was obtained through an ANU postgraduate scholarship and a RSES field allowance. Field work was also supported by a 2011 Australian-French Association for Science and Technology grant awarded to N.D. ARC-DP110103926 awarded to P.D.D. also funded part of this project. Constructive comments from M. Davies (RSES), D. Basso and 3 anonymous reviewers greatly improved earlier versions of this manuscript.

\section{LITERATURE CITED}

Adey WH, MacIntyre IG (1973) Crustose coralline algae: a re-evaluation in the geological sciences. Geol Soc Am Bull 84:883-904 
Adey WH, McKibbin DL (1970) Studies on the maerl species Phymatolithon calcareum (Pallas) nov. comb. and Lithothamnium coralloides Crouan in the Ria de Vigo. Bot Mar 13:100-106

Agegian CR (1981) Growth of the branched coralline alga, Porolithon gardineri (Foslie) in the Hawaiian Archipelago. Proc 4th Int Coral Reef Symp, Manila 2:419-423

Aguirre J, Riding R, Braga JC (2000) Diversity of coralline red algae: origination and extinction patterns from the Early Cretaceous to the Pleistocene. Paleobiology 26: 651-667

Basso D (1994) Study of living calcareous algae by a paleontological approach: the non-geniculate Corallinaceae (Rhodophyta) of the soft bottoms of the Tyrrhenian Sea (western Mediterranean). The genera Phymatolithon Foslie and Mesophyllum Lemoine. Riv Ital Paleontol Stratigr 100:575-596

Basso D (1995) Study of living calcareous algae by a paleontological approach: the genus Lithothamnion Heidrich nom. cons. from the soft bottoms of the Tyrrhenian Sea (Mediterranean). Riv Ital Paleontol Stratigr 101:349-366

Basso D (2012) Carbonate production by calcareous red algae and global change. In: Basso D, Granier B (eds) Calcareous algae and global change: from identification to quantification. Geodiversitas 34:13-33

Basso D, Nalin R, Nelson CS (2009) Shallow-water Sporolithon rhodoliths from North Island (New Zealand). Palaios 24:92-103

Bittner L, Payri CE, Maneveldt GW, Couloux A, Cruaud C, De Reviers B, Le Gall L (2011) Evolutionary history of the Corallinales (Corallinophycidae, Rhodophyta) inferred from nuclear, plastidial and mitochondrial genomes. Mole Phylogenetics Evol 61:697-713

Blake C, Maggs CA (2003) Comparative growth rates and internal banding periodicity of maerl species (Corallinales, Rhodophyta) from northern Europe. Phycologia 42:606-612

Böhm L, Schramm W, Rabsch U (1978) Ecological and physiological aspects of some coralline algae from the western Baltic. Calcium uptake and skeleton formation in Phymatolithon calcareum. Kieler Meeresforsch 4:282-288

Borowitzka MA (1983) Calcium carbonate deposition by reef algae: morphological and physiological aspects. In: Barnes DJ (eds) Perspectives on coral reefs. AIMS Contribution 200. Australian Institute of Marine Science, Townsville, p 16-27

Bosence DWJ (1983a) Description and classification of rhodoliths (Rhodoids, Rhodolites). In: Peryt TM (ed) Coated grains. Springer, Berlin, p 217-224

Bosence DWJ (1983b) The occurrence and ecology of recent rhodoliths - a review. In: Peryt TM (ed) Coated grains. Springer, Berlin, p 225-242

$>$ Bulleri F (2006) Duration of overgrowth affects survival of encrusting coralline algae. Mar Ecol Prog Ser 321:79-85

> Burdett H, Kamenos NA, Law A (2011) Using coralline algae to understand historic marine cloud cover. Palaeogeogr Palaeoclimatol Palaeoecol 302:65-70

> Cabioch J (1966) Contribution à l'étude morphologique, anatomique et systématique de deux Mélobésiées: Lithothamnium calcareum (Pallas) Areschoug et Lithothamnium corallioides Crouan. Bot Mar 9:33-53

Chan P, Halfar J, Williams B, Hetzinger S, Steneck R, Zack T, Jacob DE (2011) Freshening of the Alaska Coastal Current recorded by coralline algal Ba/Ca ratios. J Geophys Res 116:G01032
Chave KE, Wheeler BD Jr (1965) Mineralogic changes during growth in the red alga, Clathromorphum compactum. Science 147:621

> Clavier J, Garrigue C (1999) Annual sediment primary production and respiration in a large coral reef lagoon (SW New Caledonia). Mar Ecol Prog Ser 191:79-89

$>$ Debenay JP, Fernandez JM (2009) Benthic foraminifera records of complex anthropogenic environmental changes combined with geochemical data in a tropical bay of New Caledonia (SW Pacific). Mar Pollut Bull 59:311-322

Dethier MN, Steneck RS (2001) Growth and persistence of diverse intertidal crusts: survival of the slow in a fastpaced world. Mar Ecol Prog Ser 223:89-100

Eggins SM, Kinsley LPJ, Shelley JMG (1998) Deposition and element fractionation processes during atmospheric pressure laser sampling for analysis by ICP-MS. Appl Surf Sci 127-129:278-286

Fallon SJ, Guilderson TP, Caldeira K (2003) Carbon isotope constraints on vertical mixing and air-sea $\mathrm{CO}_{2}$ exchange. Geophys Res Lett 30:2289

Fallon SJ, Fifield LK, Chappell JM (2010) The next chapter in radiocarbon dating at the Australian National University: status report on the single stage AMS. Nucl Instrum Methods Phys Res B 268:898-901

> Fernandez JM, Ouillon S, Chevillon C, Douillet P, Fichez R, Gendre RL (2006) A combined modeling and geochemical study of the fate of terrigenous inputs from mixed natural and mining sources in a coral reef lagoon (New Caledonia). Mar Pollut Bull 52:320-331

Foster MS (2001) Rhodoliths: between rocks and soft places. J Phycol 37:659-667

> Frantz BR, Kashgarian M, Coale KH, Foster MS (2000) Growth rate and potential climate record from a rhodolith using ${ }^{14} \mathrm{C}$ accelerator mass spectrometry. Limnol Oceanogr 45:1773-1777

Frantz BR, Foster MS, Riosmena-Rodrìguez R (2005) Clathromorphum nereostratum (Corallinales, Rhodophyta): The oldest alga? J Phycol 41:770-773

Freiwald A, Henrich R (1994) Reefal coralline algal buildups within the Arctic Circle: morphology and sedimentary dynamics under extreme environmental seasonality. Sedimentology 41:963-984

> Freiwald A, Henrich R, Schäfer P, Willkomm H (1991) The significance of high-boreal to subarctic maerl deposits in northern Norway to reconstruct Holocene climatic changes and sea level oscillations. Facies 25:315-340

Gamboa G, Halfar J, Hetzinger S, Adey W, Zack T, Kunz B, Jacob DE (2010) Mg/Ca ratios in coralline algae record northwest Atlantic temperature variations and North Atlantic Oscillation relationships. J Geophys Res 115: C12044, doi:10.1029/2010JC006262

Goldberg N, Heine JN (2008) Age estimates of Sporolithon durum (Corallinales, Rhodophyta) from Rottnest Island, Western Australia, based on radiocarbon-dating methods. J R Soc West Aust 91:27-30

Guilderson TP, Schrag DP, Goddard E, Kashgarian M, Wellington GM, Linsley BK (2000) Southwest subtropical Pacific surface water radiocarbon in a high-resolution coral record. Radiocarbon 42:249-256

Halfar J, Zack T, Kronz A, Zachos JC (2000) Growth and high-resolution paleoenvironmental signals of rhodoliths (coralline red algae): a new biogenic archive. J Geophys Res 105:C9

Halfar J, Steneck RS, Schöne BR, Moore GWK and others (2007) Coralline alga reveals first marine record of sub- 
arctic North Pacific climate change. Geophys Res Lett 34: L07702

Halfar J, Steneck RS, Joachimski M, Kronz A, Wanamaker AD Jr (2008) Coralline red algae as high-resolution climate recorders. Geology 36:463-466

Halfar J, Hetzinger S, Adey W, Zack T and others (2011a) Coralline algal growth-increment widths archive North Atlantic climate variability. Palaeogeogr Palaeoclimatol Palaeoecol 302:71-80

Halfar J, Williams B, Hetzinger S, Steneck RS and others (2011b) 225 years of Bering Sea climate and ecosystem dynamics revealed by coralline algal growth-increment widths. Geology 39:579-582

Hallmann N, Schöne BR, Irvine GV, Burchell M, Cokelet ED, Hilton MR (2011) An improved understanding of the Alaska Coastal Current: the application of a bivalve growth-temperature model to reconstruct freshwaterinfluenced paleoenvironments. Palaios 26:346-363

Hetzinger S, Halfar J, Kronz A, Steneck R, Adey WH, Lebednik PA, Schöne BR (2009) High-resolution Mg/Ca ratios in a coralline red alga as a proxy for Bering Sea temperature variations from 1902 to 1967. Palaios 24: 406-412

Hetzinger S, Halfar J, Zack T, Gamboa G and others (2011) High-resolution analysis of trace elements in crustose coralline algae from the North Atlantic and North Pacific by laser ablation ICP-MS. Palaeogeogr Palaeoclimatol Palaeoecol 302:81-94

Hughes WW, Rosenberg GD, Tkachuck RD (1988) Growth increments in the shell of the living brachiopod Terebratalia transversa. Mar Biol 98:511-518

Kamenos NA (2010) North Atlantic summers have warmed more than winters since 1353, and the response of marine zooplankton. Proc Nat Acad Sci 107:22442-22447

Kamenos NA, Law A (2010) Temperature controls on coralline algal skeletal growth. J Phycol 46:331-335

Kamenos NA, Cusack M, Moore PG (2008) Coralline algae are global palaeothermometers with bi-weekly resolution. Geochim Cosmochim Acta 72:771-779

Le Gall L, Payri C, Bittner L, Saunders GW (2010) Multigene phylogenetic analyses support recognition of the Sporolithales ord. nov. Mol Phylogenetics Evolution 54:302-305

Littler MM, Littler DS (1988) Structure and role of algae in tropical reef communities. In: Lembi CA, Waaland JR (eds) Algae and human affairs. Cambridge University Press, Cambridge, p 30-56

Moberly R Jr (1968) Composition of magnesian calcites of algae and pelecypods by electron microprobe analysis. Sedimentology 11:61-82

> Nicet JB, Delcroix T (2000) ENSO-related precipitation changes in New Caledonia, Southwestern tropical Pacific: 1969-98. Mon Weather Rev 128:3001-3006

Ouillon S, Douillet P, Lefebvre JP, Le Gendre R and others (2010) Circulation and suspended sediment transport in a coral reef lagoon: The south-west lagoon of New Caledonia. Mar Pol Bul 61:269-296

Paillard D, Labeyrie L, Yiou P (1996) Macintosh program performs time-series analysis. EOS Trans Am Geophys Union 77:379

Pannella G (1976) Tidal growth patterns in recent and fossil mollusc bivalve shells: a tool for the reconstruction of paleotides. Naturwissenschaften 63:539-543
Payri C (1997) Hydrolithon reinboldii rhodolith distribution, growth and carbon production of a French Polynesian reef. Proc 8th Int Coral Reef Symp Panama 1:755-760

Payri C, Maritorena S, Bizeau C, Rodière M (2001) Photoacclimation in the tropical coralline alga Hydrolithon onkodes (Rhodophyta, Corallinaceae) from a French Polynesian reef. J Phycol 37:223-234

Rivera MG (1999) Edad y crecimiento de Lithothamnium crassiusculum (Foslie) Mason (Corallinales, Rhodophyta) en el suroesete del Golfo de California Mexico. BSc Thesis, Universidad Autonoma de Baja California, Mexicali

> Rodier M, Le Borgne R (2008) Population dynamics and environmental conditions affecting Trichodesmium spp. (filamentous cyanobacteria) blooms in the south-west lagoon of New Caledonia. J Exp Mar Biol Ecol 358:20-32

Schäfer P, Fortunato H, Bader B, Liebetrau V, Bauch T, Reijmer JJG (2011) Growth rates and carbonate production by coralline red algae in upwelling and non-upwelling settings along the Pacific coast of Panama. Palaios 26: 420-432

Schöne B, Tanabe K, Dettman DL, Sato S (2003) Environmental controls on shell growth rates and $\delta^{18} \mathrm{O}$ of the shallow-marine bivalve mollusk Phacosoma japonicum in Japan. Mar Biol 142:473-485

Scoffin TP, Stoddart DR, Tudhope AW, Woodroffe C (1985) Rhodoliths and coralliths of Muri Lagoon, Rarotonga, Cook Islands. Coral Reefs 4:71-80

Steneck RS (1997) Crustose corallines, other algal functional groups, herbivores and sediments: complex interactions along reef productivity gradients. Proc 8th Int Coral Reef Symp, Panama 1:695-700

Toggweiler JR, Dixon K, Broecker WS (1991) The Peru upwelling and the ventilation of the South Pacific thermocline. J Geophys Res 96:C11

Townsend RA, Woelkerling WJ, Harvey AS, Borowitzka M (1995) An account of the red algal genus Sporolithon (Sporolithaceae, Corallinales) in southern Australia. Aust Syst Bot 8:85-121

Underwood AJ (2006) Why overgrowth of intertidal encrusting algae does not always cause competitive exclusion. J Exp Mar Biol Ecol 330:448-454

Vogel JS, Nelson DE, Southon JR (1987) ${ }^{14} \mathrm{C}$ background levels in an accelerator mass-spectrometry system. Radiocarbon 29:323-333

> Wanamaker AD Jr, Hetzinger S, Halfar J (2011) Reconstructing mid-to high-latitude marine climate and ocean variability using bivalves, coralline algae, and marine sediment cores from the Northern Hemisphere. Palaeogeogr Palaeoclimatol Palaeoecol 302:1-9

Williams B, Halfar J, Steneck RS, Wortmann UG and others (2011) Twentieth century ${ }^{13} \mathrm{C}$ variability in surface water dissolved inorganic carbon recorded by coralline algae in the northern North Pacific Ocean and the Bering Sea. Biogeosciences 8:165-174

> Wilson S, Blake C, Berges JA, Maggs CA (2004) Environmental tolerances of free-living coralline algae (maerl): implications for European marine conservation. Biol Conserv 120:279-289

Womersley HBS (1996) The marine benthic flora of southern Australia, Part III B: Gracilariales, Rhodymeniales, Corallinales and Bonnemaisoniales. Australian Biological Resources Study, Canberra

Submitted: July 18, 2012; Accepted: September 28, 2012 Proofs received from author(s): January 20, 2013 